\title{
Armed Conflicts and Peace Efforts: Paradigm shift towards New world Order
}

\author{
Manali Jamkar, Ashish Deokar
}

\begin{abstract}
Conflicts and the ways of conflict resolution have prevailed since prehistoric times. Even when the Second World Warconcluded in 1945, it is observed that the number of armed conflicts hasn't been reduced. On the contrary, there has been a rise in these numbers. Opportunely the $20^{\text {th }}$ century has also seennumerous peace building efforts. A New World Order perceived by the then leaders, is seen take shape even though it is extremely dynamic in nature. This article studies the statistics of the state-based armed conflicts and peace-building efforts in the form of treaties that were taken at that time to resolve the conflicts.
\end{abstract}

Keywords: War, Peace, Technology,Economics, Conflicts

\section{INTRODUCTION}

With the absolute surrender of Germany in the west and Japan in the east, the Second World War ended in 1945. (Wilde, 2019). Since then, in spite of all the efforts to maintain peaceful relations with each other, the no. of wars around the world haven't reduced but to the contrast, increased.State-based armed conflicts have increased even after the Cold War was over. The modification in pattern from conflicts amongst states to conflicts in the states has not been inverted by the end of Cold War. The present study focuses on the post-World War armed conflicts that have occurred throughout the world and also the peace building efforts that were taken. The Uppsala Conflict Data Program has recorded an uneven but a clearly upward trend, particularly in armed international conflicts. With the help of the data gathered by the UCPD, a statistical and analytical study has thus been presented.

Before exploring the statistics presented by the UCDP and the peace efforts made by the world organisations it is important to discuss some key terms that will be included in the paper.

\section{WAR/CONFLICT}

Both terms i.e. war and conflict have been used in the study. Though the nature of the two terms are fundamentally same, there is a slight difference between them.

"Conflict can be defined as a combat between two persons or groups, over morals or claim of rank, influence and rare possessions in which the aim of conflicting sides is to assert their standards or entitlements over those of others."

Revised Manuscript Received on March 2, 2020. Corresponding Author

Manali Jamkar*,Third year BBA,BMCC,jamkarmanali98@gmail.com Ashish Deodar, Third year BBA,BMCC ashishdeokar54@gmail.com
Though this definition is frequently used simplistically and undesirably, combining all physical violence, conflict can also be seen as having an optimistic dimension as "regular form of social communication which may contribute to the preservation, development, modification and constancy of communal beings." From this perspective, conflict is 'only a problem when society cannot characterize, achieve or determine its interest in a creativemeans thus starting a degenerating or disparaging cycle of animalvehemence.' (Goodhand\& Hulme, 1999). Contention among political gatherings including threats of significant length and greatness can be regarded as War/Conflict.

Differences in perspective leads to conflict of thought and this further takes shape of a war. This can be considered as the reason why several wars have happened over the centuries and still continue to occur in the present times. Cold War is an example of two deeply rooted ideologies being cause for a conflict that resulted into numerous proxy wars. Even though the reasons behind wars have varied throughout the history, the two prominent reasons which remain valid even today are landand food. Human beings being territorial creatures have faced conflicts since prehistoric times.

Conflict is a significant subject of examination throughout many eras. In the concluding part of the twentieth century, with the outcome of two world wars and the threat of nuclear, biotic and chemical attack, more was discussed about the subject than ever before. Efforts to understand the nature of war, to verbalize some concept of its reasons, demeanour, and repulsion, caused great consequences, for conceptoutlines human forecasts and determines anthropological behaviour.The analysis of war may be divided into several classes; ethical, radical, financial, technical, legal, sociological, and emotional approaches are regularlynoted. The development of armaments of mass devastation that was followed by the World War IImade the mission of comprehending the character of war even more crucial. Secondly, war had become an obstinate social curiosity, the abolition of which seemed to be an importantrequirement for the endurance of mankind. (Wars, Britannica Encyclopaedia, Frankel, 2019).

\section{Peace}

Peace is a term that is always mentioned with the term war. It is commonly conceptualized antithesis of war, a condition in which physical confrontation does not occur.

War and Peace are often considered as two sides of the same coin. Peace is not solely about absenteeism of physical confrontation but is closelyrelated to the examination and exercise of social and commercialprogress. (Goodhand\&Hulme, 1999). Peaceful settlementdepends on the thought that war is essentially a procedure for settling questions, despite the fact that it can, obviously, additionally

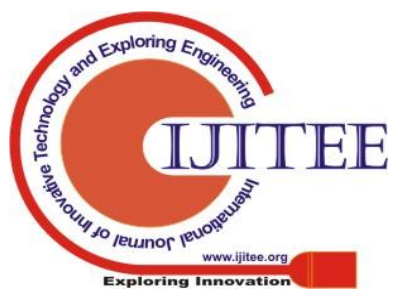


fill different needs, for example, alleviatinguncertainties and looking for position. Additionalbeliefs are that armed conflicts every now and again comes in light due to the ignorance of leaders on the possibility of settling disputes tranquilly to the commongain of both sides - an ignorance due to mere incognizance, pride, deficiency of mind's eye, or self-centred and skepticalguidance.Be any of the reasons above, the one thing is certain i.e. lack of peace. It is hencelikely that international establishments can donate to the repugnance of wars by formulating and institutionalizing substitute, diplomaticmethods for the clearing of arguments and by influencing the states to utilize them.

While talking about the sustainable development, it would be unwise to ignore the importance of peace. Conflicts and absence of security have a negativeimpression on country'sprogress, upsetting economic evolution and which often resultin disapprovals that last for long period of time. (United Nations Development Program). Therefore, it has become vital to analyse the situation in the present times and recognize the increasing trend of the armed conflicts and the its impacts.

\section{GDP}

Economicworth of all the products manufactured and amenitiescatered within a country or a region in a precise time is known as Gross Domestic Product or the GDP of the country. It is measure of its total production. Therefore, an increase in GDP is an increase in the country's production. Economic prosperity of a country can be measured through its GDP. GDP is affected by numerous factors such as natural resources, labour, human capital, technology, law etc amongst others.

Wars have been fought for economic independence and for conquering land and other properties. This makes it vital to study the economic aspect of wars and what changes have they gone through with the changing nature of the war.

\section{New World Order}

The study of International Relations tells us that the World Order has been under constant change since the 1945. The world has changed in the most rapid manner since then than other times. On the backdrop of two World Wars, there was the emergence of the New World Order, though its nature is dynamic. The need for a Global governance was felt when the League of Nations was established after World War I came to an end, whose primary motive was to rebuild Europe from the ashes. Nonetheless, the League was unable to prevent the Second World War. After the culmination of theWorld War II, deeper problems than mere political tactics were faced by the governments. The moral authoritative behind the transatlantic bargain was to defend a certain "way of life" against a different one. This strengthened the social legitimacy of the international institutions. Since then, the world order has been under constant change.

\section{Armed conflicts in the $20^{\text {th }}$ and $21^{\text {st }}$ century.}

Shortly after the WW II, the USA and their associates and the Soviet Union and its allied states divulged into the Cold
War that went on for years. The North Atlantic Treaty Organisation, NATO, was formed by US and its European allies in 1949. The Soviet Union formed alliances with Mainland China as both shared the same philosophy of communism. The world, again faced with the prospect of Nuclear War with the Cuban missile crisis, was fortunately saved, but the political tensions around the world were risen since then. Amidst the efforts to establish peace, wars have been a constant companion for nearly every nation in the world.

According to the Uppsala Conflict Data Program, there have been $\mathbf{2 8 3 5}$ armed conflicts over the period of 72 years. The study of the armed conflicts in which at least one party is a state government reveals that contrasting many beliefs of reduction in the number of wars after thesecond world war, the number of armed conflicts taking place every year has been on a rise.

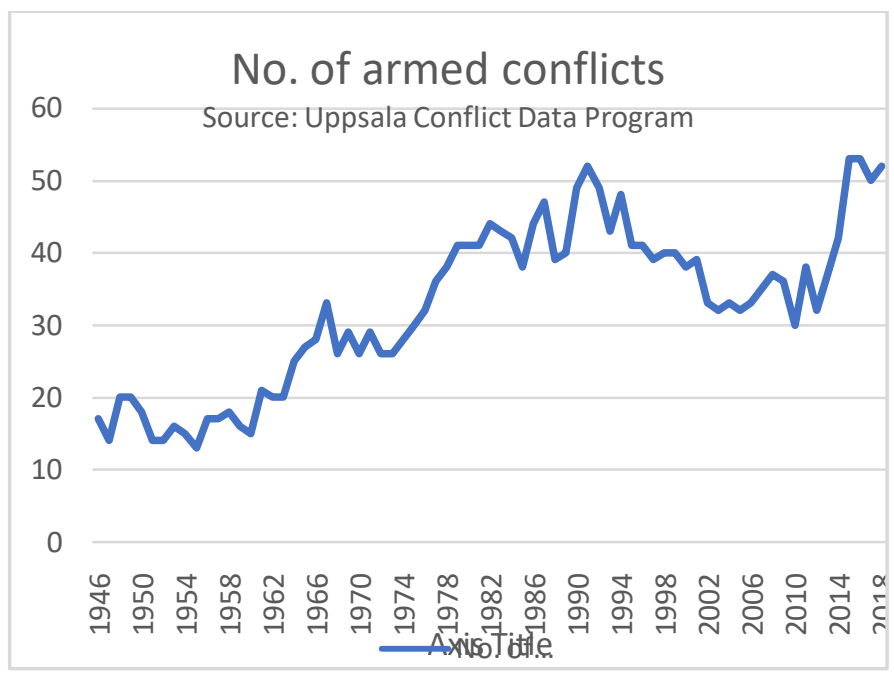

The graph represents all the armed conflicts that took place afterwards the conclusion of World War II. The general trend of the graph can be seen as increasing. Throughout the Cold War, the soldiers of the U.S. and the Soviet Union never fought directly but continually provoked each other through dogmaticmanoeuvring, martialalliances, intelligence, propaganda, weapons manufacturing, economic assistance and proxy wars between the other countries. One such proxy war was the Korean war, where the Soviet reinforced communist government of North Korea to invade the South Korea which was backed by the U.S in 1950 .

The Korean war continued till 1953. Tensions among the Super powers relaxed in the span of 1953 to 1957 but another powerful stage of the Cold War came in 1958-62 with the Cuban missile crisis in 1962, a clash that carried the two superpowers at the edge of war before an agreement was signed to extract the missiles. In the span of two decades of 1946 to 1966 , one can see the armed conflicts have almost doubled. The number of armed conflicts that happened around the world in 1946 were 17 and the number of conflicts in 1967 were 33. During the cold war and even after its end, the world has witnessed a large number of conflicts that led to casualties in large numbers.U.S. and the Soviet engaged into different military confrontations indirectly on the European soil. Both the sides wanted to refrain their allies from 
joining the other side. The Soviet directed troops to reserve the communist rule in East Germany (1953), Czechoslovakia (1968), Hungary (1956), and Afghanistan (1979).

The U.S., on its part assistedin taking over a left-wing government in Guatemala (1954), supported anfailedassault on Cuba (1961) and entered the Dominican Republic (1965) and Grenada (1983). The Vietnam War that continued from 1964-75 was an unsuccessful attempt by The United States of America to avert communist North Vietnam from trying to bring South Vietnam under its rule. Even after the end of Vietnam war, we can notice a sharp rise in the numbers of conflicts from 1973 to 1982 . The number of wars per year has gone from 26 in 1973 to 47 in 1982 . Here too, we can see that the numbers have been doubled. The bipolar struggle between the superpowers gave way to more complexglobal relations between the 1960 s to 70 s where multipolarity came into picture. The harmony of the communist bloc was shattered because of a key split that occurred between the Soviet Union and mainland China. Countries of western Europe and japan became economically stronger dropping their comparativesubordination to the United States. The 1970s saw easing of the cold war tension. In 1980s the two superpowers sustained their arms built-up and contested for impact in the 'Third World'. Europe collapsed in 1989-90, the U.S.S.R. was disintegrated and democratic republics came into existence. The conflicts reached a peak in 1991 with 52 wars happening in that year.

Struggles in the middle east have also been on a sharp rise. The Arab-Israeli conflict of 1948 involved Egypt, United Arab Rebellion, Syrian Republic, Jordan, Lebanon, Israel and the Palestinian Authorities. The Suez War of 1956 in which Israel, France and Britain invaded Egypt. The Six-day War of 1967 where Israel launched a pro-active attack on Egypt, Jordan and Syria. Israel also attacked the Iraqi airforce. The Iraq-Iran war went for 9 years between 1980-88 involving Iraq, Iran and Kuwait. This is also known as the First Gulf War. The Second Persian Gulf war that took place in 1990-91 involved Iraq vs. Kuwait, Saudi Arabia, Egypt, Syria, Britain, France, Oman, Qatar, UAE and the United States. The Third Persian Gulf War happened from 20032011. It was the second foremost war between the U.S-led alliance and the middle eastern state of Iraq. The Iran-Israel proxy conflict took place in 2006 and Iran-Saudi Arabia proxy conflict in2011. The First Gaza War happened in 2008-2009, the Second Gaza War in 2012 and the Third Gaza War in 2014.

\section{Casualties}

The effects of the armed conflicts have resulted in heavy casualties. This study only focuses on the loss of life happened due to a conflict in which at least one party is a state-based government. Even though the number of armed conflicts has been on a rise, the number of battle related deaths have declined. In the initialyears succeeding the war, around half a million people deceasedbecause of direct vehemence in wars; in opposition to 2016, the number of all the deaths caused by conflicts involving one state has been 87,432.

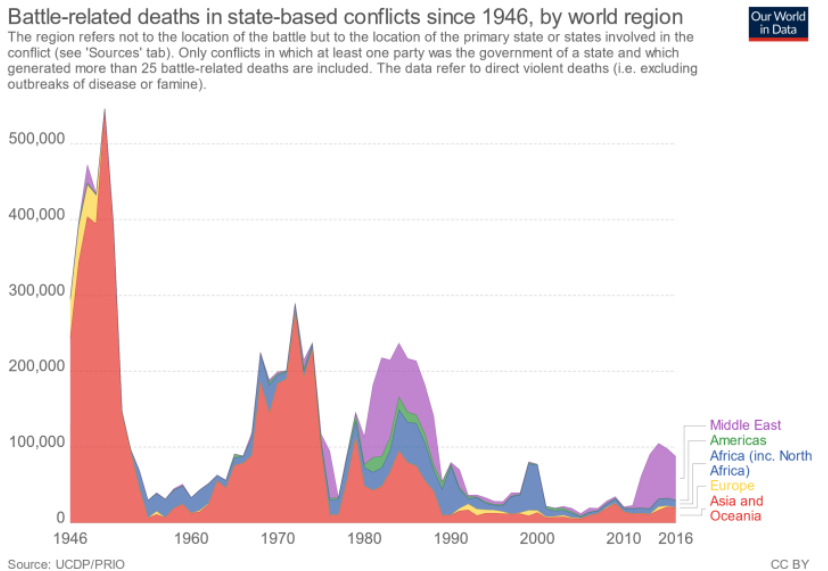

The above graph focuses on the number of deaths caused by the state-based conflicts in the time period 1946 to 2016. In general, it can be observed that the number of deaths due to armed conflicts has fluctuated over the time period of 6 decades. It can be clearly seen that the highest number of deaths was in 1950s (Korean War; early 1950s). After that the number is seen to be decreased but only to increase in 1972 (Vietnam war of the 1970s). Till the 1975s Asia has been the continent with maximum number of deaths. In the year 1950, out of the total 546,501 deaths 524,211 deaths were of Asian people. Over the years, the violence in the middle east has also increased. In the year 1982, the number of deaths in the middle east were 130,037 out of the total 217,647 (Iraq-Iran and Afghanistan wars in 1980s).In between 1990 to 2010 the number of deaths has been remarkably low. There has been freshupsurge in the deaths caused by conflict in Middle East, especially in Syria, Iraq and Afghanistan.

\section{GDP and Armed Conflicts}

The study of the world GDP from 1945 to 2015 indicates a growth. The trendline of the graph is also upwards. There is a direct association amid the world GDP and number of armed conflicts happening.



Other from the human cost of war, there also an economic cost of war that has to be taken into consideration to understand the correlation between the World GDP and Armed conflicts. As there are negative impacts of the war on the economy like inflation, damages to the infrastructure, rise in national debt and psychological costs, there are also some positive effects of war on the economy. Full employment is one of the economic benefits of the war.

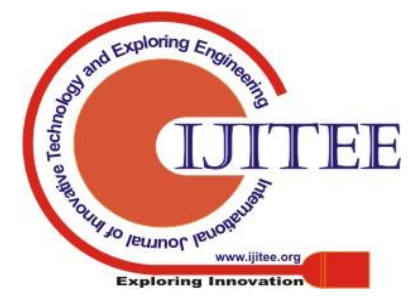




\section{Armed Conflicts and Peace Efforts: Paradigm shift towards New world Order}

The second benefit that has hugely impacted the society is the boost in innovation and science.During the war, the government invests more in the research and development of technology. All the nuclear inventions of the $20^{\text {th }}$ century are results of the two great wars. The economic boom of the 1960s was also a result of the wars happening in Korea, Vietnam and Cambodia. US was involved in major conflicts in these three nations in the 50s and the 60s. this resulted in the increase in the domestic demand as military spending increased and this increase in demand further resulted in higher economic growth. Also, the nature of wars has changed. Armed conflicts are more concentrated in some regions than other regions but with effects all over the world. For example, the conflict in middle east is the cause of immigrant problem in Europe.

\section{Efforts for peace}

Along with the conflicts, the efforts to maintain peace can also be seen during the time period of 72 years (1946-2018). There have been many treaties over the years and many organisations established with the UN itself being established in 1945. Few of the important mentions are included in this study.

\section{$20^{\text {th }}$ Century:}

The $20^{\text {th }}$ century saw most horrific wars but it also witnessed the most consorted peace exertions ever endeavoured to limit and avert a war.The Atlantic charter was signed and the United Nations organisation came into existence in 1945. It can be said that UN struggled with its agenda of peaceful cooperation as the world surged into the Cold War. But over the years there have been many attempts to maintain peace.

In July 1953, Korean armistice agreement was contracted in Panmunjom, marking an end to the Korean War. In 1956 witnessed establishment of the'United Nations Peacekeeping force'. The UNEF I (UN's Emergency Force) confinedand observeda ceasefire concluding the Sinai war between UK, Egypt, France and Israel forming a barricade zone, dissuadingmilitary activity in the border area and safeguard asettlement between Egypt and Israel. Eventually in 1967, Egyptforced the UNEFI to withdraw. The Antarctic treaty signed in 1969 in Washington opened gate to peace post-world war 2 arms control treaty, and both internationalised and removed all the military forces on the continent. The 'UN'sConference on Diplomatic Interaction and Immunities', adopted the Vienna Convention on Diplomatic Relations, outlining the instructions of diplomatic law. In 1961, the U.S. Peace Corps was created by the then U.S. President John. F. Kennedy. The same year Amnesty International, an organisation devoted to defending rights of people around the world was founded. In 1963, between the Soviet Union and USA a MOU was signed in Genevaforming a connection of communication "Hot Line". Organisation of African Unity, (OAU), was also formed in '63 to endorse international collaboration and accord in African states, amongst other resolutions. The OAU has arbitrated and resolved a number of international and internal African Conflicts. Convention on the Prohibition of the Development, Production and Stockpiling of Bacteriological and Toxic Weapons and on Their Destruction was signed in April 1972 and came into force in March, 1975. On 25 ${ }^{\text {th }}$ May, 1972, Agreement on the prevention of Incidents, on and over the High Seas was signed in Moscow, amid U.S.S.R and America on the next day, i.e. on $26^{\text {th }}$ May, 1972, between the two powerful nations a temporary contract on certain measures, w.r.t Strategic Offensive Arms limitation was also signed. The treaty restricted the number of tacticalairborne missiles permitted each country.

On $27^{\text {th }}$ January, 1973, between U.S, North Vietnam, South Vietnam and the Viet Cong the 'Paris Treaty of Peace' was authorised with an intention of ending the Vietnam war. It provided stabledevelopment in the zones of European Security, demilitarization, self-assurance, humanitarian activities, economic, technology and other fields. The 'Environment Modification (ENMOD) Convention' was contracted in Geneva in 1976, restricting military or other aggressive use of environmental alterationsystems.

With the intention of subduing the rising conflict and establishing broader peace in the Middle East, 'The Camp David Accords', touched in Camp David in between United States of America, Egypt and Israel, launchingagenda for Israel-Egypt peace treaty in 1978. In 1979, the peace treaty was signed between the two countries in Washington D.C. in June 1979, the SALT II was also signed between the U.S and U.S.S.R. This treaty was never approved but it set equivalentlimit on tacticalweaponries and restricted certain categories of arms instruments in its terms. The UNGA i.e. UN's General Assembly declared September 21 as 'International Day of Peace' in the year 1981. The United Nations Convention on $10^{\text {th }}$ April 1981, eliminating and limitingparticular categories of weaponries such as antipersonnel mines and combustible weapons counter to civilians was signed in New York.

In Helsinki, America, Canada and all the European countries (excluding Albania) sealed the 'Helsinki final Act'. The Helsinki Process or CSCE was a result of this act. The beforehand announcement of key troop activities in European territory was demanded by the Document on Confidence Building Measures in Europe sealed by the Commission in Security and Cooperation in Europe CSCE in 1983. "Convention against torture, and other cruel, inhumane and degrading treatment or punishment." Or "The Torture Convention was adopted by the UN General Assembly in 1984. The Stockholm session on "The Disarmament and Security Building in Europe" was authorised in 1986 in by the members of CSCE in Stockholm. Notice of significant military manoeuvres, and on-site check was notified in the agreement among other measures. Participating countries were all member states and Soviet Union and United States. "Conventional Armed Forces in Europe Treaty" was endorsed in Paris to bound NATO and Warsaw Pact aircrafts, weaponry and other armed facilities in Europe in 1990. "Charter of Paris for a new Europe" was also initialled by the members of CSCE in 1990. "The Indo-Sri Lankan accord" was signed by the

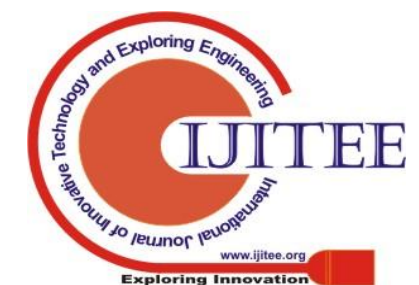


governments of India and Sri Lanka on July 29, 1987 in Colombo.

In the year 1989, the Berlin Wall was eliminated re-joining the East and West Germany. George Bush, the then President of U.S.A., and Mikhail S. Gorbachev, the U.S.S.R President, ended the Cold War in the 'Malta Summit' on 3 December, 1989. In 1991, 'Strategic Arms Reduction Treaty' (START I) was signed in between the U.S and the Soviet Union in Moscow. The agreement provided abolition of certain tactical weapons to the level of 6000 deployed missiles. The'Second Strategic Arms Reduction Treaty' (START II) was authorized in 1993, also in Moscow, reducing the number of strategic arsenals to maximum 3500 warheads. "The Oslo accords" or "The declaration of Principles of Interim Self-government Arrangements" was signed in Washington on September 13, 1993 between Israel and the Palestinian Liberation Organisation. In theMayof 1994, 'Gaza Strip and Jericho Area Agreement', was ratified in the city of Cairo between Palestinian Liberation Organisation \& Israel providing establishing of Palestinian Authority which further followed the removal of the Israeli powers from Gaza and Jericho Area. In the year 1994 then U.S.A. President Bill Clinton sealed the "Washington Declaration" with the King Hussein of Jordan and then Israeli Prime Minister, Yitzhak Rabin, pledging Israel and Jordan working towards a peaceful arrangement. In 1994, Agreement on "Preparatory transfer of powers and responsibilities" was initialled by Israel and the PLO at Erez. The 'Wye river memorandum' in 1998 and 'Sharm elSheikh memorandum on implementations' signed in 1999 between the PLO and Israel. Israel and Jordan worked a peace agreement on October 26, 1994 at the Arava/Araba crossing point. The "Dayton Peace Accords", a general agreement for peace in Herzegovina and Bosnia initialled in Dayton, Ohio was approved in Paris in 1995. In the same year 'The Oslo process' was advanced due to the Interim Agreement on the West Bank and Gaza Strip.

The treaty of "Central American democratic security", was employed in Panama, San Pedro, Nicaragua, Sula, El Salvador, Honduras, Guatemala and Costa Rica promoting human rights, arms control and peace. The "Good Friday Agreement"comprising of the governments of Republic of Ireland, UK, and other key political parties from Northern Ireland including Loyalists \&Republics, was a "Multilateral Northern Ireland Peace Agreement" ratified in 1998.

\section{$21^{\text {st }}$ century:}

The cold war ended in the year 1989, but its impacts were seen in the after years. Nevertheless, efforts to maintain and establish peace continued.

In 2005, to sponsor the post-conflict redevelopment, United Nation's "Peacebuilding Commission" was founded. In the same year, Declarationsupportiveof the doctrine "Responsibility to Protect" was sanctioned in 2005 "World Summit' of the UN General Assembly. The Geneva Declaration on 'Armed Violence and Development' was accepted in 2006, obligatingparticipants totake actions upon the tasks of the state and civil society onavoiding and decreasing weapon violence, and inserting armed violence within a developmental setting. A United Nations in a declarationannounced October 2, the birth anniversary of Mahatma Gandhi the "International Day of Non-Violence" in 2007. The "Convention on Cluster Munitions", an international treaty prohibiting cluster bombs was signed in 2008 and entered into force in 2010. Russia and America switched the Treaty of Moscow (SORT) and signed the"New Strategic Arms Reduction Treaty" (START)in 2010.

The "Framework Agreement on the Bangsamoro", anintroductory peace agreement was approved on 15 October 2012 in the Malacañang Palace in Manila, Philippines. The "Comprehensive Agreement on Bangsamoro" (CAB), a concluding peace treaty between the Government of the Philippines and the Moro Islamic Liberation Front came into existence on 27 March 2014 at the Malacañang Palace in Manila. Since 2015, the "Final Colombian Peace Agreement" between the government of Colombia and Revolutionary Armed Forces of Colombia (FARC) in 2016 has been the one that resulted in conclusion of the ongoing conflict. The 2017 Cairo Declaration (also known as SPLM Declaration of Unification) came into existence on November 16, 2017 at the headquarters of Egyptian General Intelligence in Cairo, Egypt.The document was an effort with the intent to connect and terminate the SPLM civil war in South Sudan, including the homecoming of immigrants and exiledpeople to their homes. Eritrea's President Isaias Afewerki and Abiy Ahmed vowed to reinstatepolitical relations and opened their borders in July 2018. On 9 July, they entered the "Joint Declaration of Peace and Friendship between Eritrea and Ethiopia", which formally terminated the "EritreanEthiopian" border struggle. A closing peace agreement, where both countries accepted to enforce the "EritreaEthiopia Boundary Commission's" decision, was approved on 16 September 2018.

These two treaties relax discordancy and are hence regarded as full peace agreements. On 12 September 2018, a part peace agreement was settled between (SPLM/A - IO), the Southern Sudanese authorities and the Sudan People's Liberation Movement/Army in Opposition "The Revitalised Agreement on the Resolution of the Conflict in the Republic of South Sudan" (R-ARCSS).

\section{TREATIES REGARDING THE NUCLEAR WEAPONS}

Second world war saw the practice of nuclear weapons as nuclear bombs were dropped on Hiroshima and Nagasaki. The effects of the terrible event shook the whole world and specific efforts were taken to avoid repetition of such conflict.

(SANE), "National Committee for Sane Nuclear Policy" was established in the city of New York in 1957. "SANE"in 1986 combined with "Nuclear Weapons Freeze Campaign" and became"SANE/FREEZE" and then in 1993 was turned into"Peace Action". In 1958, the "Campaign for Nuclear Disarmament" was established in the Britain. In 1967, the 'Treaty for Prohibition of Nuclear Arms in Latin American region' (Treaty of Tlatelolco) was ratified in Mexico, restricting the use of Nuclear weapons in Latin America. There were 5 nuclear-free provincial zones established through a treaty in which the 'Treaty of Tlatelolco' was the first. In 1971, the Treaty 
prohibiting "Nuclear Missiles or Other Weaponries of Mass Destruction on the Ocean Base" was madeconcurrently in London, Moscow and Washington. This treaty was implemented in 1972. In 1973, the "Treaty on Prevention of Nuclear War" was signed by the U.S. and U.S.S.R. in Washington. In 1974, the "Threshold Test Ban Treaty" was authorized at Moscow. The PNE Treaty (Treaty between Soviet Union and the USA on "Underground Nuclear Detonation for Peaceful Purposes") was authorised in Moscow. This treatyoversees all nuclear-powered explosions outside of selectedarmaments test sites stated in the "Threshold Test Ban Treaty"signed in 1974."South Pacific Nuclear Free Zone Treaty" (Treaty of Rarotonga) at Rarotonga, New Zealand Cook Island by Australia, and other 11, minor Pacific island nationswere authorised in 1985. Treaty on the "Abolition of transitional and shorterrange missiles" (INF or Intermediate Range Nuclear Force Treaty) was signed between the Super powers in 1987 at Washington. JointStatement of the "Denuclearisation of the Korean Peninsula" was signed by two Korean governments in 1992 in Vienna. Ten nations of Southeast Asia signed the "Treaty of Bangkok", in Bangkok by for a Nuclear Free Zone in 1995 was entered into force by 1997. In 1996, the "African Nuclear-Weapon-Free-Zone" Treaty was certified by 50 African countries.

\section{New world order of today}

Atlantic charter was signed and the UN was formed thus ending the world war II in 1945 but the war between the two philosophies of Capitalism and communism continued further. The Cold War that happened between the superpowers, United States of America and Union of Soviet Socialist Republic had the world on its toes as many governments feared another Nuclear war. In many ways, it truly changed the nature of conflicts and went on for several years. The descent of the Berlin Wallwith the disintegration of the U.S.S.R into multiple smaller countries marked the official end of cold war. The technological development and change in the political environment are undoubtedly some major factors that are responsible for the face of the armed conflicts that we see today, but the ideological facet added by the Great Powers has made equal contribution. Mikhail Gorbachev, who came to power in The Soviet Union in 1985 started a revolution by introducing policies like 'glasnost' and 'perestroika' that ultimately ended the cold war in 1991. Glasnost (meaning "openness") strategyimprovement while the exact meaning of perestroika is "restructuring", stating that the restructuring of the Soviet administrative and economic system. Gorbachev was the first politician to introduce the term 'New World Order'. The cold war, that included the proxy wars in Korea, Vietnam and Cambodia and aftermaths of the cold war, which are majorly seen in the middle east has caused more casualties and loss of life and economic destruction than the second world war.

\section{CONCLUSION}

Many scholars were of the opinion that there wasn't a specific winner party of the Cold War.It cost the USA trillions of dollars to prepare for a direct conflict with the Soviet Union that luckily never arose. Nevertheless, it cost the US the lives of thousand soldiers whilepursuingsubstitution wars in Vietnam and Korea. (ushistory.org, 2019) Even after the end of the world war we continue to notice rise in the armed conflicts in which the state governments are involved. The world has changed gradually from unipolar to bipolar to multipolar world. There is a change in power centre across the world with new power centres coming up. To be more specific the shift of power centre has been from West to East. Countries like China and India are projected to become the major power centres in the coming times while organisations like ASEAN and BRICS are slowly and gradually gaining more and more political influence in the international scenario.The First World War was about acquiring land. World War II was about the hearts and minds of different philosophies. International security is aindistinctstability and it may not take much for it to descend into a global war in a world of 7.5 billion people.

Multiple factors are responsible for the changing times. Termination of bipolarity with developing countries coming to forefront, several countries turning democratic, increasing trend of globalisation of information as well as economic power, efforts taken to maintain international cooperation and security, desperate and sometimes-violent ways used to protect and claim the rights on cultural identities, sovereignty redefined are few to state. Due to these alterations organised violence has changed its nature and governments and other organisations have adopted different ways to mark their boundaries. The notablereduction in $1900 \mathrm{~s}$ in the international combats and the death toll caused because of it is one of the signs of change.

Subnational,culturalconflicts and war based on religions, however, has had such an impact that the first decade succeeding the Cold War was marked by manyfatalconflicts of lower intensityand it happened to be the most suffering since the arrival of nuclear missiles. The nature of the armed conflicts has changed and the trends have become more critical in past few years. Growing intricacy and asymmetric warfare are connected. Conflicts aren't spread out but concentrated to regions. Wars go on for decades as there is a lack of an effective international system that can provide conflict resolution. On top of that we have cases of failed national systems too.Barring few exemptions, majority of the wars that have happened in the last few years are outcome of the "conflict trap", wars creating wars, both sidesbreaking and increasing, and new parties superseding in ongoing wars. Tensions that have not been solved for years continue to exhaust resources and affect the society and the means of strength of the distressed.

In this ongoing chaos, one might wonder where the humanity is actually headed. With different ideologies separating us, are we failing to sustain tolerance? While struggling to sustain the resources on the planet and our homes and communities we should also take an effort to sustain the humanitarian ideologies and values that are a part of the reality that we have created for ourselves. While protecting "our way of life", we should respect other "ways of life". The real question that one can ask is, are we propagating sustainable humanity?

\section{REFERENCES:}

1. AbyetG, (2018), We Must Work Together to Build A New World Order. This Is How We Can Do It, retrieved from

2. https://weforum.org/2018/12/we-must-work-together-to-build-a-newworld-order-china-russia-us/

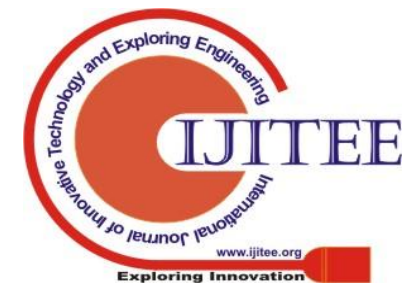


3. Agarwal P, (2019), What Is Economic Growth, Intelligent Economics, retrieved from

4. https://intelligenteconomics.com/economic-growth/

5. Colombian peace process, Wikipedia, retrieved from https://en.m.wikipedia.org/wiki/Colombian_peace_process\#Ratificati on

6. Gleditsch, Petter N., Wallensteen P., Erikson M., Sollenberg M., and Strand H, (2002), Armed conflict 1946-2001: New dataset. Journal of Peace Research 39(5)

7. Goodhand J, Hulme D, (1999), From wars to complex political emergencies: Understanding conflict and peacebuilding in the new world disorder, Third World Quarterly, 20:1, 13-26, DOI 10.1080/01436599913893.

8. historyguy.com, War List of Middle Eastern Conflicts, retrieved from https://historyguy.com/list_of_wars_middle_east.html

9. International Conflict Resolution After the Cold War (2000), Chapter: Conflict Resolution in a Changing World, retrieved from https://www.nap.edu/read/9897/chapter/2

10. John. F. Kennedy, Presidential Library and Museum, The Cold War, retrieved from https://jkflibrary.org/learn/about-jkf/jfk-in-history/thecold-war

11. Joseph Frankel,War,Encyclopaedia Britannica (2019), retrieved fromhttps://www.britannica.com/topic/war

12. Mishra P, (2015) Current Global Political Scenario And Importance Of Peace Keeping Initiate, LinkedIn, retrieved from https://www.linkedin.com/pulse/current-global-political-scenarioimportance-peace-keeping-mishra

13. Nye Joseph, Jr. (1992), What New World Order, Foreign Affairs, retrieved from

14. http://www.foreignaffairs.com/articles/1992-03-01/what-new-worldorder

15. Peace treaties, Wikipedia, retrieved from https://en.wikipedia.org/wiki/Category:Peace_treaties

16. Petterson, Therese; Hogbladh S. and Oberge M, 2019. Organised violence, 1989-2018 and peace arrangements, Journal of Peace Research, 56 (4)

17. Pettinger T, (2019), Economic Impact of War, Economics Help, retrieved from

18. https://economicshelp.org/blog/2180/economics/economic-impact-ofwar/

19. Roser M, (2019) - "Economic Growth". Published online at OurWorldInData.org, retrieved from:

20. https://ourworldindata.org/economic-growth/

21. Roser M, (2019) "War and Peace". Published online at OurWorldInData.org, retrieved from https://ourworldindata.org/warand-peace

22. The Editors of Encyclopaedia Britannica, (2019, August 30), Cold War, retrieved from https://www.britannica.com/events/Cold-War

23. unhistory.org (2019), The End of Cold War, retrieved from https://unhistory.org/us/59e.asp

24. United Nations Development Program, Goal 16- Peace, Justice and Strong Institutions, retrieved from https://undp.org/content/undp/en/home/sustainable-developmentgoals/goal-16-peace-justice-and-strong-institutions.html

25. United States Institute of Peace, (2013), Peace Event of The $20^{\text {th }}$ and $21^{\text {st }} \quad$ Century, retrieved from https://www.usip.org/sites/default/files/2017-

01/Peace $\% 20$ Events $\% 20$ of $\% 20$ the $\% 2020$ th $\% 20$ and $\% 2021$ st $\% 20$ Cent uries.pdf

\section{AUTHORS PROFILE}

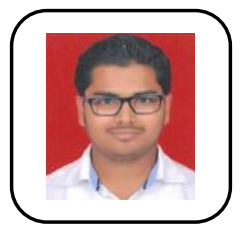

Ashish Deokar

Third Year Student of BBA(IB) at BrihanMaharashtra

College of Commerce, Pune.

Email: ashishdeokar54@gmail.com

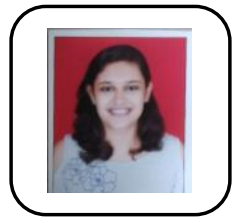

\section{Manali Jamkar}

Third Year Student of BBA(IB) at Brihan Maharashtra

College of Commerce, Pune.

Email: jamkarmanali98@gmail.com 